\title{
High seroprevalence of Toxoplasma gondii and Neospora spp. in stray dogs from Rolim de Moura, Rondônia state, Western Brazilian Amazon
}

\section{Alta soroprevalência de Toxoplasma gondii e Neospora spp. em cães errantes de Rolim de Moura, estado de Rondônia, Amazônia Ocidental Brasileira}

Henrique Momo Ziemniczak; Maerle Oliveira Maia²; Maiara Oliveira Maia'; Elvino Ferreira ${ }^{3}$; Nayche Tortato Vieira4; Klaus Casaro Saturnino ${ }^{5}$; Katia Denise Saraiva Bresciani6; Ana Amélia Domingues Gomes"; Richard de Campos Pacheco;; Thaís Rabelo dos Santos-Doni ${ }^{* *}$

\section{Highlights}

Toxoplasma gondii and Neospora spp. is widespread in dogs of Rolim de Moura, Rondônia.

Seroprevalence of T. gondii was $82.20 \%$ and of Neospora spp. was $73.85 \%$, in stray dog.

First report of seroprevalence of the T. gondii and Neospora spp. in dogs, Rondônia.

We report the highest seroprevalence of Neospora spp. in dogs, in Brazil.

High prevalence of T. gondii at Rolim de Moura, Rondônia state, Brazil.

\section{Abstract}

Toxoplasma gondii and Neospora spp. are important apicomplexan pathogens that can infect dogs and result in a neurological syndrome. The aim of this study was to evaluate the seroprevalence of $T$. gondii

1 Graduating Students of Veterinary Medicine, Department of Veterinary Medicine, Universidade Federal de Rondônia, UNIR, Rolim de Moura, RO, Brazil. E-mail: henrique.momo@hotmail.com; maiara.maia28@hotmail.com

2 Doctoral Student, Postgraduate Program in Veterinary Sciences, Faculdade de Medicina Veterinária, Universidade Federal do Mato Grosso, UFMT, Cuiabá, MT, Brazil. E-mail: maerlemaiafm@hotmail.com

3 Prof. Dr., Department of Veterinary Medicine, UNIR, Rolim de Moura, RO, Brazil. E-mail: elvinoferreira@yahoo.com.br

4 Prof., M.e, Department of Veterinary Medicine, UNIR, Rolim de Moura, RO, Brazil. E-mail: professor_nayche@yahoo. com.br

5 Prof. Dr., Universidade Federal de Goiás, U'FG, Jataí, GO, Brazil. E-mail: klauscasaro@gmail.com

6 Profa Dra, Universidade Estadual de São Paulo, UNESP, School of Veterinary Medicine, Araçatuba, SP, Brazil. E-mail: katia.bresciani@unesp.br

7 Profa Dra, Universidade Federal do Vale do São Francisco, UNIVASF, Petrolina, PE, Brazil. E-mail: ana.ameliadg@ hotmail.com

8 Prof. Dr., Postgraduate Program in Veterinary Sciences, UFMT, Cuiabá, MT, Brazil. E-mail: pachecorc@gmail.com

9 Profa Dra, Universidade Federal dos Vales do Jequitinhonha e Mucuri, UFVJM, Unaí, MG, Brazil. E-mail: rabelo.vet@ hotmail.com

* Author for correspondence

Received: Mar. 10, 2021 - Approved: July 27, 2021 
and Neospora spp. in stray dogs in the state of Rondônia, Brazil. A cross-sectional study was conducted from June 2014 to April 2016. A total of 458 dogs blood samples were collected at the Center for Control of Zoonosis (CCZ), and anti-T. gondii and anti-N. spp. antibody levels were detected and measured using indirect fluorescent antibody test (IFAT). The seroprevalence of T. gondii and Neospora spp. in dogs it was $82.20 \%$ and $73.85 \%$, respectively. The seroprevalence of coinfections was $47.59 \%$. This is the first report of anti-T. gondii and anti-Neospora spp. antibodies detected in stray dogs in Rolim de Moura, state of Rondônia, Western Brazilian Amazon. Male dogs showed a higher frequency of anti-T. gondii antibodies than female dogs (88.0\% vs. $75.3 \%$; $p<0.001$ ), presenting 2.41 times more chances of having the disease. High seroprevalence of infection (92.4\%: T. gondii and 89.2\%: Neospora spp.) was detected in the group $\geq 1$-year-old dogs, in all collections, with OR 7.35 and OR 10.27 for the presence of anti-T. gondii and antiNeospora spp., respectively. In conclusion, the serological results indicate an important circulation of $T$. gondii and Neospora spp. in wandering dogs hailing from Rolim de Moura, state of Rondônia, Western Brazilian Amazonia.

Key words: Toxoplasmosis. Neosporosis. Canine. Brazil. Prevalence. IFAT.

\section{Resumo}

Toxoplasma gondii e Neospora spp. são importantes patógenos apicomplexos que podem infectar cães e ocasionar síndrome neurológica. O objetivo deste estudo foi avaliar a soroprevalência de $T$. gondii e Neospora spp. em cães errantes do estado de Rondônia, Brasil. Um estudo transversal foi realizado durante o período de junho de 2014 a abril de 2016. Um total de 458 amostras de sangue de cães foram colhidas no Centro de Controle de Zoonoses (CCZ) e a detecção de anticorpos contra T. gondii e N. spp. foram realizados pela reação de imunofluorescência indireta (RIFI). A soroprevalência de T. gondii e Neospora spp. em cães foi $82,20 \%$ e $73,85 \%$, respectivamente. A soroprevalência de coinfecções foi $47,59 \%$. Este é o primeiro relato de anti-T. gondii e anti-Neospora spp. anticorpos detectados em cães errantes em Rolim de Moura, estado de Rondônia, Amazônia Ocidental Brasileira. Os cães machos apresentaram maior frequência de anticorpos anti-T. gondii do que as fêmeas (88,0\% vs. 75,3\%; $p<0,001)$, apresentando 2,41 vezes mais chance de ter a doença. Alta soroprevalência de infecção (92,4\%: T. gondii e 89,2\%: Neospora spp.) foi detectada no grupo $\geq$ cães com 1 ano de idade, em todas as coletas, com OR 7,35 e OR 10,27 para presença do anti-T. gondii e anti-Neospora spp., respectivamente. Em conclusão, os resultados sorológicos indicam uma importante circulação de T. gondii e Neospora spp. em cães errantes de Rolim de Moura, estado de Rondônia, Amazônia Ocidental Brasileira.

Palavras-chave: Toxoplasmose. Neosporose. Canino. Brasil. Prevalência. RIFI.

\section{Introduction}

Toxoplasma gondii and Neospora spp. are important apicomplexan pathogens characterized as obligatory intracellular protozoan. Both diseases have widespread geographical distribution and the capacity to infect homoeothermic animals (Dubey, Lago, Gennari, Su, \& Jones, 2012). Toxoplasma gondii is responsible for major economic losses in livestock and, it is a public health problem owing to the possibility of its transmission to 
humans (Belluco, Simonato, Mancin, Pietrobelli, \& Ricci, 2018).

Toxoplasma gondii and the related parasite $N$. caninum are cosmopolitan coccidians that cause neurological diseases in domestic dogs (Canis familiaris). In addition to behaving as intermediate hosts for T. gondii and Neospora spp., they can carry oocysts in their fur, thereby favouring human infection in cases of $T$. gondii, due to the close relationship; contaminated the environment and infecting a wide range of intermediate hosts (Langoni, Fornazari, Silva, Monti, \& Villa, 2013).

Surveys conducted in Brazil showed that there was variation in the seroprevalence of $T$. gondii and $N$. caninum in dogs from different states. Few studies have been conducted in relation to these parasites in animals in the Amazon region. Therefore, the studies carried out in the state of Rondônia on the occurrence of anti-T. gondii antibodies noted $76.4 \%$ in dogs, (Canon-Franco et al., 2004) whereas the presence of $N$. caninum antibodies was 8.3\% (Canon-Franco et al. 2003) and 12.6\% (Aguiar et al., 2006) in dogs.

In this context, the objective of this study was to evaluate the seroprevalence of T. gondii and Neospora spp. in stray dogs from the state of Rondônia, Brazil and correlate possible variables associated with seropositivity for these protozoans.

In this study, all procedures using animals complied with the Ethical Principles in Animal Research adopted by the College of Animal Experimentation and were approved (protocol number PP010/2014) by the Ethical Committee for Animal Welfare, UNIR, Rolim de Moura, Rondônia, Brazil.

This study was conducted in animals from the municipality of Rolim de Moura
(6148'13"S, 6148'12"W), Rondônia state, in the Western Brazilian Amazon. This region presents a climate that, according to Aw of Köppen classification, was characterized as equatorial with changes to the hot and humid tropical climate with a well-defined dry season from March to September, minimum and maximum temperatures of $17^{\circ} \mathrm{C}$ and $33^{\circ} \mathrm{C}$, respectively, with precipitation between high and moderately high (2000 to $2250 \mathrm{~mm}$ ) and $85 \%$ relative air humidity. It has an area of $1,487.35 \mathrm{~km}^{2}$ with an estimated population of 55,407 inhabitants and an altitude of 261 meters above the sea level.

The number of samples was calculated, assuming that the expected frequency of both $T$. gondii and $N$. spp. are approximately $50 \%$ to maximize the sample size, to obtain a minimal confidence level of $97 \%$, and maintain the statistical error under 1\%. Calculations were executed using an Epilnfo program (CDC, version 7.1.5.2), thereby resulting in a minimal sample size of 434 dogs (Thrusfield \& Christley, 2018). This number was determined based on the human population existing in the municipality and on the calculation of the proportion dog:man, that is, 1:10 (Reichmann, Pinto, \& Nunes., 1999), which resulted in a population of 5,541 dogs. A total of $10 \%$ of the sample population was added to the sample size; therefore, the final study population size was 478 dogs.

The study was carried out in the municipality of Rolim de Moura in the state of Rondônia, Brazil (Western Brazilian Amazon), and samples were collected from all dog shelters, in Center for Control of Zoonosis (CCZ). The blood samples were collected from 458 mixed breed dogs (Canis familiaris) from June 2014 to April 2016, and a cross-sectional study was also performed. The data were 
grouped based on the year of collection (1st 2014, 2nd-2015, and 3rd-collections of 2016). Amongst these, 152, 167 and 159 samples were collected from the years 2014, 2015 and 2016. Information on age (< one year or $\geq$ one year) and sex (female or male) were obtained through physical examination. Blood samples from dogs were collected by venepuncture (cephalic or jugular), using identified vacuum tubes, after collection, which were packed in polystyrene with icex and centrifuged at 1000 $\mathrm{g}$ for $10 \mathrm{~min}$. Subsequently, the serum was separated in a specific tube. Serum samples were identified and maintained at $-20^{\circ} \mathrm{C}$ until serological tests were performed.

Anti-T. gondii and anti-Neospora spp. antibody levels were detected and measured by means of indirect fluorescent antibody test (IFAT). The RH strain of the T. gondii and $N$. caninum tachyzoites (NC-1) was maintained in Vero cell cultures. We used an anti-dog IgG conjugate label led with fluorescein isothiocyanate $\left(\right.$ Sigma $^{\circledR}$, St. Louis, MO), as a secondary antibody, with a cut-off dilutions values of 1:16 (Arraes-Santos et al., 2016) and 1:50 (Gondim, Lindsay, \& McAlliester, 2009) for $T$. gondii and $N$. caninum, respectively. Reactions in which tachyzoites presented total fluorescence were deemed positive. Positive and negative control sera were added to each slide.

To compare the infection rates of the two parasites, Pearson's Chi square $(\chi 2)$ test or Fisher exact tests were performed to evaluate the differences between variables. For inferential statistics, the seroprevalence of T. gondii infection was considered as the dependent variable, and other factors were considered as the explanatory or independent variables. In each year, indexes of the prevalence, Odds ratios (OR), confidence interval $(\mathrm{Cl})$ of $95 \%, \chi 2$, and $P$ value were separately calculated for each variable. All statistical tests were performed using STATA/ SE, Version 16.1, Software (Stata Corp LLC, College Station, Texas, USA), considering a significance level of $5 \%$.

In the present study, the prevalence of toxoplasmosis and neosporosis amongst dogs were $82.20 \%(392 / 478 ; 95 \% \mathrm{Cl}$ : 78.3185.19) and 73.85\% (353/478; 95\% Cl: 69.7377.59), respectively.

The seroprevalence of $\mathrm{T}$. gondii was $67.76 \%$ (95\% Cl: 59.97-74.68) in 2014, $89.22 \%$ (95\% Cl: 83.61-93.07) in 2015 and $88.05 \%$ (95\% Cl: 82.09-85.19) in 2016. For the presence of anti-T. gondii antibodies, a statistical difference was observed in the various collections ( $\chi 2=30.728, p<0.0001)$, where the seroprevalence performed in 2014 was lower and statistically significant that in the other samples in the following years. Regarding Neospora spp., referring to the 2014, 2015 and 2016 samples, the percentage of dogs with positive reactions according to IFAT were 79.61\% (95\% Cl: 72.51-85.24), 70.06\% (95\% Cl: $62.73-76.49)$ and $72.33 \%(95 \% \mathrm{Cl}: 64.91-$ 78.98), respectively. No significant difference was found in the seroprevalence of infection by Neospora spp., amongst the 2016 samples ( $\chi 2=4,040, p=0.133)$.

The male dogs had a higher frequency of anti-T. gondii antibodies than the female dogs $(88.0 \%$ vs. $75.3 \%$; $p<0.001)$, showing that the former were 2.41 times more likely to have the antibodies. In the analysis of gender for the presence of anti-Neospora spp. antibodies, no statistical difference ( $p>0.05$ ) was found in all the studied collections. The results related to the comparison between male and female dogs are shown in Table 1. 
Table 1

Univariable analysis of risk factors associated with seroprevalence of $T$. gondii and $N$. spp. in dogs from Rolim de Moura, Rondônia state, Western Amazon, Brazil

\begin{tabular}{|c|c|c|c|c|c|c|c|c|c|c|}
\hline \multirow[b]{3}{*}{ Variable } & \multicolumn{10}{|c|}{ Seroprevalence (IFAT - IgG) } \\
\hline & \multicolumn{5}{|c|}{ Toxoplasma gondit } & \multicolumn{5}{|c|}{ Neospora spp. } \\
\hline & $\begin{array}{c}\text { Reagent } \\
\text { n (\%) }\end{array}$ & $\begin{array}{c}\text { Non- } \\
\text { Reagent } \\
\text { n (\%) }\end{array}$ & Total & $\begin{array}{c}\mathrm{OR}^{\mathrm{a}} \\
(95 \% \\
\mathrm{Cl})\end{array}$ & p-value ${ }^{b}$ & $\begin{array}{c}\text { Reagent } \\
\text { n (\%) }\end{array}$ & $\begin{array}{c}\text { Non- } \\
\text { Reagent } \\
n(\%)\end{array}$ & Total & $\begin{array}{c}\mathrm{OR}^{\mathrm{a}} \\
(95 \% \\
\mathrm{Cl})\end{array}$ & $p$-value ${ }^{b}$ \\
\hline \multicolumn{11}{|l|}{ Sex } \\
\hline female & $\begin{array}{c}171 \\
(75.3)\end{array}$ & $\begin{array}{c}56 \\
(24.7)\end{array}$ & $\begin{array}{c}227 \\
(75.3)\end{array}$ & 1 & 0.001 & $\begin{array}{c}168 \\
(74.0)\end{array}$ & $\begin{array}{c}59 \\
(26.0)\end{array}$ & $\begin{array}{c}227 \\
(74.0)\end{array}$ & $\begin{array}{c}1.02 \\
(0.68- \\
1.53)\end{array}$ & 0.94 \\
\hline male & $\begin{array}{c}221 \\
(88.0)\end{array}$ & $\begin{array}{c}30 \\
(12.0)\end{array}$ & $\begin{array}{c}251 \\
(88.0)\end{array}$ & $\begin{array}{c}2.41 \\
(1.48- \\
3.92)\end{array}$ & & $\begin{array}{c}185 \\
(73.7)\end{array}$ & $\begin{array}{c}66 \\
(26.3)\end{array}$ & $\begin{array}{c}251 \\
(73.7)\end{array}$ & 1 & \\
\hline \multicolumn{11}{|c|}{ Age } \\
\hline$<1$ year & $\begin{array}{c}102 \\
(62.2)\end{array}$ & $\begin{array}{c}62 \\
(37.8)\end{array}$ & $\begin{array}{c}164 \\
(62.2)\end{array}$ & 1 & $<0.0001$ & $\begin{array}{c}73 \\
(44.5)\end{array}$ & $\begin{array}{c}91 \\
(55.5)\end{array}$ & $\begin{array}{c}164 \\
(44.5)\end{array}$ & 1 & \\
\hline 1 year & $\begin{array}{c}290 \\
(92.4)\end{array}$ & $\begin{array}{c}24 \\
(7.6)\end{array}$ & $\begin{array}{c}314 \\
(92.4)\end{array}$ & $\begin{array}{c}7.35 \\
(4.36- \\
12.39)\end{array}$ & & $\begin{array}{c}280 \\
(89.2)\end{array}$ & $\begin{array}{c}34 \\
(10.8)\end{array}$ & $\begin{array}{c}314 \\
(89.2)\end{array}$ & $\begin{array}{l}10.27 \\
(6.41- \\
16.44)\end{array}$ & $<0.0001$ \\
\hline
\end{tabular}

a OR: odds ratio. Reference group marked as $\mathrm{OR}=1$;

${ }^{\text {b Pearson's Chi Square }}$

* Significant association $(p<0.05)$.

The dogs were further allocated to two groups aged < one year $(\mathrm{n}=164)$ and $\geq$ one year $(n=314)$ for statistical analysis (Table 1). Compared with the young dogs (62.2\%: T. gondii and 45.5\%: N. spp.), a higher seroprevalence of infection (92.4\%: T. gondii and $89.2 \%$ : N. spp.) was detected in the group $\geq$ one-year-old dogs, in all collections ( $p<$ 0.05), with a OR 7.35 (95\% Cl: 4.36-12.39; $p<$ 0.0001 ) and OR 10.27 (95\% Cl: 6.41-16.44; $\mathrm{p}<$ $0.0001)$ for the presence of the anti-T. gondii and anti-Neospora spp., respectively.

Seroprevalence of T. gondii in the order of $82.20 \%$ and of $N$. spp. of $73.85 \%$ were found in this research. This is the first report of anti- $T$. gondii and anti-N. spp. antibodies detected in stray dogs in Rondônia state, Brazil (Western
Brazilian Amazon). This high prevalence may be explained by geographic characteristics such as the hot and humid climate in the Amazon region, which is geographically, socially and ecologically different from the climate in other parts of the world with high levels of precipitation, which may contribute towards higher viability among oocysts in the environment. Figliuolo et al. (2004) showed that differences in altitude and temperature in certain areas may explain serological differences, as hot areas promote higher seroprevalence and sporulation of oocysts than colder regions.

In the present study, the prevalence of co-infections ( $T$. gondii and $N$. spp.) was 47.59\%. We observed that T. gondii and N. spp. 
are widely spread in the studied region. The $T$. gondii seroprevalence in dogs was higher than the $N$. spp. seroprevalence, which is a frequent finding (Mascolli et al., 2015).

In prevalence studies of the $T$. gondii the rates of positive dogs vary highly. In Brazil, the seroprevalence in dogs can range from $3.1 \%$ to $91 \%$ in different regions (Dubey et al., 2012). In this survey, the seroprevalence for toxoplasmosis (82.2\%) were similar to those reported by Canon-Franco et al. (2004), which showed the presence of anti- $T$. gondii antibodies in $76.4 \%$ of domiciled dogs in the city of Monte Negro, Rondônia.

In Brazil, the seroprevalence of $N$. caninum ranges from $0.7 \%$ to $67.6 \%$, with a mean of $13.72 \%$ (95\% Cl: 11.32-16.32) (Anvari et al., 2020). In the present study, we report the highest seroprevalence of $N$. spp. (73.85\%) in dogs, in Brazil. The results obtained in the present study were similar to those observed by Lasri, De Meerschman, Rettigner, Focant and Losson (2004), with respect to three different dog populations in Belgium, who reported that $76.3 \%$ (71/93, ELISA) of canines are positive. Studies carried out in the Rondônia state showed positivity for $N$. caninum (IFAT < $50)$ in the order of $8.3 \%(13 / 157)$ in domiciled dogs (Canon-Franco et al., 2003) and 12.6\% (22/174) in rural dogs (Aguiar et al., 2006). The rates were much lower than those found in this research, and this difference can probably be explained by the wide spread of the agent in the environment.

There was a significant difference between T. gondii infection and gender $(\mathrm{p}<$ 0.001). The male dogs showed 2.41 (1.48-3.92) times the risk of being infected with $T$. gondii than female dogs. Mascolli et al. (2015) have suggested that sexually active stray male dogs travel long distances and, therefore, they are more exposed to contaminated environments than female dogs, which, in turn, increases the latter's risk of infection. Unlike for neosporosis, the sex of the dogs was not associated ( $p=$ 0.94) with positive results in serological tests, and these results are in agreement with those cited by Anvari et al. (2020).

High seroprevalence of infection (92.4\%: T. gondii and 89.2\%: N. spp.) was detected in the group $\geq$ one-year-old dogs, in all collections $(p<0.0001)$. This high infection has been related to a greater probability for exposure to T. gondii and Neospora spp. over time, thereby increasing the susceptibility in older dogs (Watanabe et al., 2020).

High prevalence of $T$. gondii in street dogs than in pets suggests that the habit of eating infected prey is an important source of infection. From an epidemiological point of view, this finding is interesting, especially considering the zoonotic role of $T$. gondii. They do actas important indicators of environmental contamination with $T$. gondii because of their close association with humans (Souza et al., 2019).

In conclusion, these serological results indicate an important circulation of $T$. gondii and $N$. spp. in stray dogs in the Rolim de Moura, Rondônia state, Western Brazilian Amazon. The presence of antibodies against T. gondii and N. spp. in carnivores is a good indicator of environmental contamination with the parasites. Integrated control strategies are recommended to prevent and control toxoplasmosis and neosporosis, despite the intimate contact between dogs and humans. 
Conflicts of interest/Competing interests

The authors declare that they have no competing interests.

\section{Ethics approval}

In this study, all procedures using animals complied with the Ethical Principles in Animal Research adopted by the College of Animal Experimentation and were approved (protocol number PP010/2014) by the Ethical Committee for Animal Welfare, UNIR, Rolim de Moura, Rondônia, Brazil.

\section{Competing interests}

The authors declare that they have no competing interests.

\section{Availability of data and material}

The datasets used and analyzed during the current study are available from the corresponding author on request.

\section{References}

Aguiar, D. M., Cavalcante, G. T., Rodrigues, A. A., Labruna, M. B., Camargo, L. M., Camargo, E. P., \& Gennari, S. M. (2006). Prevalence of anti-Neospora caninum antibodies in cattle and dogs from Western Amazon, Brazil, in association with some possible risk factors. Veterinary Parasitology, 142(1-2), 71-77. doi: 10.1016/j.vetpar.20 06.06 .014
Anvari, D., Saberi, R., Sharif, M., Sarvi, S., Hosseini, S. A., Moosazadeh, M.,... Daryani, A. (2020). Seroprevalence of Neospora caninum infection in dog population worldwide: a systematic review and metaanalysis. Acta Parasitologica, 65(2), 273290. doi:10.2478/s11686-019-00163-4

Arraes-Santos, A. I., Araujo, A. C., Guimaraes, M. F., Santos, J. R., Pena, H. F. J., Gennari, S. M.,... Horta, M. C. (2016). Seroprevalence of anti-Toxoplasma gondii and antiNeospora caninum antibodies in domestic mammals from two distinct regions in the semi-arid region of Northeastern Brazil. Veterinary Parasitology: Regional Studies and Reports, 5, 14-18. doi:10.1016/j.vp rsr.2016.08.007

Belluco, S., Simonato, G., Mancin, M., Pietrobelli, M., \& Ricci, A. (2018). Toxoplasma gondii infection and food consumption: A systematic review and meta-analysis of case-controlled studies. Critical Reviews in Food Science and Nutrition, 58(18), 3085-3096. doi:10.1080/10408398.2017 .1352563

Canon-Franco, W. A., Bergamaschi, D. P., Labruna, M. B., Camargo, L. M., Silva, J. C., Pinter, A., \& Gennari, S. M. (2004). Occurrence of anti-Toxoplasma gondii antibodies in dogs in the urban area of Monte Negro, Rondonia, Brazil. Veterinary Research Communications, 28(2), 113-118. doi: 10.1023/B:VERC.00 00012114.71235 .73

Canon-Franco, W. A., Bergamaschi, D. P., Labruna, M. B., Camargo, L. M., Souza, S. L., Silva, J. C..... Gennari, S. M. (2003). Prevalence of antibodies to Neospora caninum in dogs from Amazon, Brazil. Veterinary Parasitology, 115(1), 71-74. doi:10.1016/s0304-4017(03)00131-6 
Dubey, J. P., Lago, E. G., Gennari, S. M., Su, C., \& Jones, J. L. (2012). Toxoplasmosis in humans and animals in Brazil: high prevalence, high burden of disease, and epidemiology. Parasitology, 139(11), 1375-1424. doi: 10.1017/S0031182012 000765

Figliuolo, L. P., Kasai, N., Ragozo, A. M., Paula, V. S. de, Dias, R. A., Souza, S. L., \& Gennari, S. M. (2004). Prevalence of anti-Toxoplasma gondii and anti-Neospora caninum antibodies in ovine from Sao Paulo State, Brazil. Veterinary Parasitology, 123(3-4), 161-166. doi:10.1016/j.vetpar. 2004.06.006

Gondim, L. F. P., Lindsay, D. S., \& McAlliester, M. M. (2009). Canine and Bovine Neospora caninum control sera examined for crossreactivity using Neospora caninum and Neoposra hugnesi indirect fluorescent antibody tests. Journal of Parasitology, 95(1), 86-88. doi: 10.1645/GE-1710.1

Langoni, H., Fornazari, F., Silva, R. C. da, Monti, E. T., \& Villa, F. B. (2013). Prevalence of antibodies against Toxoplasma gondii and Neospora caninum in dogs. Brazilian Journal of Microbiology, 44(4), 13271330. doi: 10.1590/S1517-8382201300 0400043

Lasri, S., De Meerschman, F., Rettigner, C., Focant, C., \&Losson, B. (2004). Comparison of three techniques for the serological diagnosis of Neospora caninum in the dog and their use for epidemiological studies. Veterinary Parasitology, 123(1-2), 25-32. doi:10.1016/j.vetpar.2004.05.025
Mascolli, R., Soto, F. R. M., Bernardi, F., Ito, F. H., Pinheiro, S. R., Guilloux, A. G. A.,... Vasconcellos, S. A. (2015). Seroprevalence and risk factors for toxoplasmosis and neosporosis in the dog population of Ibiúna, São Paulo, Brazil. Semina: Ciências Agrárias, 36(6), 3777-3786. doi: 10.5433/1679-0359.2015v36n6p3777

Reichmann, M. L. A. B., Pinto, H. B. F., \& Nunes, V. F. P. (1999). Vacinação contra a raiva de cães e gatos.

Souza, I. B., Fernandes, P. R., Silva, T. R. M., Santos, C. V. B., Silva, N. M. M. da, Ubirajara, C. R. C. Fo.,... Ramos, R. A. N. (2019). Seroprevalence of Neospora caninum and Toxoplasma gondii in dogs from an urban area of north-eastern Brazil: a spatial approach. Revista da Sociedade Brasileira de Medicina Tropical, 52. doi: 10.1590/0037-8682-0440-2018

Thrusfield, M., \& Christley, R. (2018). Veterinary epidemiology (4nd ed.). Cambridge: Blackwell Science.

Watanabe, M., Sadiq, M. B., Mulop, N. I. A., Mohammed, K., Rani, P. A. M., Fong, L. S.,... Syed-Hussain, S. S. (2020). Prevalence of Toxoplasma gondii antibodies in stray dogs from various locations in west and east Malaysia. Korean Journal of Parasitology, 58(5), 487-492. doi: 10.3347/ kjp.2020.58.5.487 